\title{
The roles of tumor necrosis factor-alpha in colon tight junction protein expression and intestinal mucosa structure in a mouse model of acute liver failure
} Hong-Li Song1,2, Sa Lv1,3 and Pei Liu*1

Address: ${ }^{1}$ Department of Infectious Diseases, The First Affiliated Hospital, China Medical University, Shenyang 110001, Liaoning Province, PR China, ${ }^{2}$ Current address: Department of Organ Transplantation, Tianjin First Central Hospital, Tianjin, 300192, PR China and ${ }^{3}$ Current address: The 5th Department of Infectious Disease, 302 Military Hospital of China, Beijing 100039, PR China

Email: Hong-Li Song - hlsong26@yahoo.com.cn; Sa Lv - lvsa@sina.com; Pei Liu* - syliupei2003@yahoo.com.cn

* Corresponding author

Published: 22 September 2009

BMC Gastroenterology 2009, 9:70 doi:10.1 I86/I47I-230X-9-70

This article is available from: http://www.biomedcentral.com/I47I-230X/9/70

(C) 2009 Song et al; licensee BioMed Central Ltd.

This is an Open Access article distributed under the terms of the Creative Commons Attribution License (http://creativecommons.org/licenses/by/2.0), which permits unrestricted use, distribution, and reproduction in any medium, provided the original work is properly cited.
Received: II April 2009

Accepted: 22 September 2009

\begin{abstract}
Background: Spontaneous bacterial peritonitis (SBP) is a common clinical disease and one of the most severe complications of acute liver failure (ALF). Although the mechanism responsible for SBP is unclear, cytokines play an important role. The aim of this study was to investigate the effects of tumor necrosis factor-alpha (TNF- $\alpha$ ) on the structure of the intestinal mucosa and the expression of tight junction (Zona Occludens I; ZO-I) protein in a mouse model of ALF.

Methods: We induced ALF using D-galactosamine/lipopolysaccharide (GaIN/LPS) or GaIN/TNF$\alpha$ and assessed the results using transmission electron microscopy, immunohistochemistry, Western blotting, ELISA and real-time quantitative PCR. The effects of administration of anti-TNF$\alpha \lg \mathrm{G}$ antibody or anti-TNF- $\alpha$ RI antibody before administration of GalN/LPS or GalN/TNF- $\alpha$, respectively, on TNF- $\alpha$ were also assessed.

Results: Morphological abnormalities in the intestinal mucosa of ALF mice were positively correlated with serum TNF- $\alpha$ level. Electron microscopic analysis revealed tight junction (TJ) disruptions, epithelial cell swelling, and atrophy of intestinal villi. Gut bacteria invaded the body at sites where TJ disruptions occurred. Expression of ZO-I mRNA was significantly decreased in both ALF models, as was the level of ZO-I protein. Prophylactic treatment with either anti-TNF- $\alpha$ IgG antibody or anti-tumor necrosis factor-a receptorl (anti-TNF- $\alpha$ RI) antibody prevented changes in intestinal tissue ultrastructure and ZO-I expression.

Conclusion: TNF- $\alpha$ affects the structure of the intestinal mucosa, decreases expression of ZO-I, and affects the morphology of the colon in a mouse model of ALF. It also may participate in the pathophysiological mechanism of SBP complicated to ALF.
\end{abstract}

\section{Background}

Acute liver failure (ALF) is a devastating disease associated with high mortality. Spontaneous bacterial peritonitis (SBP), a common clinical disease, is one of the most severe complications of ALF and a major cause of death [1-4]. However, the mechanism responsible for SBP is unclear. Previous studies reported that the serum level of tumor necrosis factor- $\alpha$ (TNF- $\alpha$ ) is elevated in patients 
with severe liver injury and is positively associated with serum lipopolysaccharide (LPS) level $[5,6]$. TNF- $\alpha$ is a cytokine with broad-spectrum physio-and patho-responsiveness and is primarily secreted by monocaryons and macrophages. In addition to participating in humoral and cellular immune responses, TNF- $\alpha$ also plays an important role in diseases such as severe hepatitis, septic shock, and inflammatory bowel disease [7-10]. However, it is not known whether TNF- $\alpha$ affects the barrier function of the intestinal mucosa.

The intestinal mucosa is a physical and metabolic barrier against toxins and pathogens in the lumen of the gut. Tight junctions (TJs) are the main structures responsible for restricting paracellular movement of compounds across the intestinal mucosa. Structurally, TJs are composed of cytoplasmic proteins, including the zona occludens proteins, ZO-1, ZO-2, and ZO-3 [11,12] and two distinct transmembrane proteins, occludin and claudin $[13,14]$, which are linked to an actin-based cytoskeleton [15]. TJs function as occluding barriers by maintaining cellular polarity and homeostasis and by regulating the permeability of paracellular spaces in the epithelium [16]. ZO-1, a member of the MAGUK family of proteins, acts as a scaffold for organizing transmembrane TJ proteins and recruits various signaling molecules and the actin cytoskeleton to the TJs [17]. Although previous studies have afforded an insight into the molecular structure of TJs, much less is known about TJ functionality under physiological or pathophysiological conditions. Few studies have described intestinal mucosa ultrastructure or changes in TJs during liver failure. In this study, we used ALF animal models to investigate the effect of TNF- $\alpha$ on the ultrastructure of the intestinal mucosa with emphasis on the role of TJs.

\section{Methods}

\section{Animals and treatment}

Male, six-to eight-week-old BALB/c mice (China Medical University) were obtained from the China Medical University (Shenyang, China). They were housed and cared for in rooms maintained at a constant temperature and humidity. Food and water were allowed ad libitum. Food was withdrawn the evening before the experiment. All animal experimental procedures were approved by the Ethics Committee of China Medical University before the commencement of the study.

All mice were randomly divided into eight groups $(\mathrm{n}=8$ per group). One group of mice was given intraperitoneal injections of D-galactosamine (GalN; $800 \mathrm{mg} / \mathrm{kg}$ body weight; Sigma, Saint Louis, USA) and LPS (10 $\mu \mathrm{g} / \mathrm{kg}$ body weight; Sigma) to induce ALF. A second ALF-induction group was also given intraperitoneal injections of GalN (800 mg/kg body weight) and TNF- $\alpha(10 \mu \mathrm{g} / \mathrm{kg}$ body weight; Sigma). Two groups were given antibody treatments prior to ALF induction: one was given anti-TNF- $\alpha$ IgG (100 $\mu$ g per mouse; US Biological, USA) and the other was given anti-TNF- $\alpha$ R1 antibody (100 $\mu \mathrm{g}$ per mouse; R\&D Systems, USA). The anti-TNF- $\alpha$ IgG and anti-TNF- $\alpha$ $\mathrm{R} 1$ antibodies were injected via the vena caudalis $30 \mathrm{~min}$ utes and 15 minutes before GalN/LPS administration. There were four control groups, which were injected intraperitoneally with GalN, LPS, TNF- $\alpha$, or NS.

In summary, the eight groups were: 1) GalN/LPS; 2) GalN/TNF- $\alpha$; 3 ) GalN control; 4) LPS control; 5) TNF- $\alpha$ control; 6) NS control; 7) anti-TNF- $\alpha$ IgG and GalN/LPS; and 8) anti-TNF- $\alpha$ R1 antibody and GalN/LPS. Mice in the first six aforementioned groups were euthanized 2, 6, 9, 12 and $24 \mathrm{~h}$ after treatment. Mice in the last two of the aforementioned groups were euthanized $9 \mathrm{~h}$ after administration of GalN/LPS. The study was approved by the Ethics Committee of China Medical University.

\section{Serum TNF-a assay}

Serum levels of alanine transaminase (ALT) were determined using an automatic analyzer (Hitachi, Japan). Serum levels of TNF- $\alpha$ were determined using an ELISA kit (R\&D Systems) according to the manufacturer's protocol.

\section{Detection and observation of intestinal mucosal ultrastructure}

Ultrathin $(70 \mathrm{~nm})$ intestinal sections were examined using a transmission electron microscope (Hitachi H-600, Japan).

\section{Immunohistochemical detection of ZO-I in frozen tissue sections}

Frozen intestinal tissue sections ( $5 \mu \mathrm{m}$ thick) were fixed on glass slides by incubating them in acetone for $10 \mathrm{~min}$ at $4{ }^{\circ} \mathrm{C}$. The slides were incubated with $3 \% \mathrm{H}_{2} \mathrm{O}_{2}$ for 20 minutes at room temperature and indirectly immunolabeled using an $\mathrm{ABC}$ kit (Takara, Japan) according to the manufacturer's instructions. Slides were then blocked in goat serum for $30 \mathrm{~min}$ at $37^{\circ} \mathrm{C}$ and incubated with a rabbit anti-mouse polyclonal ZO-1 antibody (dilution, 1:50; Santa Cruz Biotechnology, USA) at $4{ }^{\circ} \mathrm{C}$ overnight. For the negative controls, the primary antibody was replaced with PBS. This incubation was followed by incubation with biotinylated goat anti-rabbit IgG (Histostain-Plus kit, ZYMED) diluted 1:300 in PBS for $2 \mathrm{~h}$ at room temperature. Sections were rinsed in PBS and then in distilled water. The slides were stained with 3, 3'-diaminobenzidine and counterstained with hematoxylin.

\section{Western blot analysis of tissue ZO-I content}

Intestinal tissue samples were homogenized in lysis buffer (20 mM Tris-HCl [pH 7.5], 1\% Triton X 100, $0.2 \mathrm{M} \mathrm{NaCl,}$ 2 mM EDTA, 2 mM EGTA, 1 M DTT and $2 \mathrm{M}$ aprotinin). 
Proteins $(50 \mu \mathrm{g})$ were electrophoresed using SDS-PAGE $(8 \%)$ and transferred to a nitrocellulose membrane. Membranes were blocked with non-fat dried milk in TBS containing $0.05 \%$ Tween-20 (TTBS) for $1 \mathrm{~h}$ at room temperature and incubated with a rabbit anti-mouse polyclonal ZO-1 antibody (diluted 1:400; Santa Cruz Biotechnology) at $4{ }^{\circ} \mathrm{C}$ overnight. After three washes in TTBS, the membranes were reacted with a 1:2000 dilution of alkaline phosphatase-labeled goat anti-rabbit IgG (Santa Cruz Biotechnology) for $2 \mathrm{~h}$ at room temperature. The immunoreaction was visualized using $\alpha$-dianisidine and $\beta$-naphthyl acid phosphate (Sigma, USA).

\section{RNA isolation and real-time quantitative PCR}

Total RNA was isolated from intestinal tissues using TRIzol Reagent (Invitrogen, USA). RNA was purified using DNase I and depurified using PI-PCI-EHCO. SYBR-greenbased real-time PCR (TaKaRa SYBR RT-PCR kit, Japan) was used to measure relative gene expression in each sample. First, we prepared an RNA standard (forward 5'-TTCCGGGTCGTGGATACTT-3', reverse 5'GTTCCCAGCTTATGAAAGGGTT-3', amplicon size 327 bp) and determined standard curves for the ZO-1 gene and a house-keeping gene (GAPDH RNA standard forward 5'-CAGCCGCATCTTCTTGTG-3', reverse 5'AGGAGCGAGACCCCACTAA-3', amplicon size 335 bp). PCR was performed using Taq DNA polymerase (Qiagen, Valencia, USA) and oligonucleotide primers for mouse ZO-1 (forward 5'-CGAGGCATCATCCCAAATAAGAAC-3', reverse 5'-TCCAGAAGTCTGCCCGATCAC-3', amplicon size $97 \mathrm{bp}$ ) and glyceraldehyde 3-phosphate dehydrogenase (GAPDH; forward 5'-AAATGGTGAAGGTCGGTGTG3', reverse 5'-TGAAGGGGTCGTTGATGG-3', amplicon size $108 \mathrm{bp})$. PCR conditions were as follows: one cycle at $95^{\circ} \mathrm{C}$ for 30 minutes followed by 45 cycles of PCR amplification, each consisting of $95^{\circ} \mathrm{C}$ for $5 \mathrm{~s}$ and $60^{\circ} \mathrm{C}$ for 20 $\mathrm{s}$. The concentration of mRNA was calculated according to the standard curve and then normalized to that of GAPDH.

\section{Statistical analysis}

SPSS version 10.0 Software was used to perform the statistical analyses. All data were analyzed using analysis of variance (ANOVA) followed by a least-squares difference test. $P$ values $<0.05$ were considered significant. All data are presented as the mean \pm SE.

\section{Results}

The effect of TNF- $\alpha$ in mice with GaIN/LPS-induced ALF

Most ALF mice $(66.7 \%, 90 / 120)$ died between $6 \mathrm{~h}$ and 12 $\mathrm{h}$ after the GalN/LPS injection. Serum ALT levels increased significantly $6 \mathrm{~h}$ after the GalN/LPS injection compared with the control groups $(P<0.01)$ (Table 1$)$. Serum TNF$\alpha$ levels reached a maximum value $(446.18 \pm 55.49 \mathrm{pg} /$ $\mathrm{ml}) 2 \mathrm{~h}$ after the GalN/LPS injection and then decreased to $14.82 \pm 9.02 \mathrm{pg} / \mathrm{ml}$ at $6 \mathrm{~h}$ after the GalN/LPS injection
(Figure 1). The second highest TNF- $\alpha$ level was observed $9 \mathrm{~h}$ after the GalN/LPS injection $(319.43 \pm 33.72 \mathrm{pg} / \mathrm{ml})$. Liver histopathology showed massive or submassive necrosis at $9 \mathrm{~h}$ after the GalN/LPS injection. We successfully used TNF- $\alpha$ in place of LPS to induce ALF in conjunction with GalN. The ALT levels and histopathological characteristics of the GalN/TNF- $\alpha$ group were similar to those of the GalN/LPS group. As the ALF mice that died 9 h $(60 \%, 54 / 90)$ after GalN/LPS administration displayed levels of serum biochemical markers and liver morphology consistent with liver failure, we assessed the protective effects of anti-TNF- $\alpha$ IgG and anti-TNF- $\alpha$ R1 antibodies on liver failure $9 \mathrm{~h}$ after induction of ALF. The mortality of mice treated with either of the two antibodies was $0 \%(0 /$ 8 ). ALT serum levels were only slightly elevated and decreased rapidly compared with GalN/LPS-treated mice $(P<0.01)$. Histopathological examination showed only spot or focal hepatonecrosis.

\section{Ultrastructural characteristics of the intestinal mucosa}

We observed obvious ultramicrostructural changes in the intestinal mucosa after GalN/LPS administration. Some epithelial cell microvilli were disarranged and distorted, and they were sparsely distributed. The epithelial cells were swollen or shrunken. The mitochondrial matrices were swollen, cristae were breaked and the TJs were disrupted. The changes in the intestinal mucosa of mice treated with GalN/TNF- $\alpha$ were similar to those of mice treated with GalN/LPS. Some TJs were disrupted in the treatment groups, but there was no disruption of TJs in the control groups, only swelling of epithelial cells. Pathological changes in groups that were treated with antibodies were less severe than those in the ALF groups (Figure 2).

\section{Bacterial invasion of the intestinal mucosa}

Under TEM showed that bacterial invasion of the intestinal mucosa began between $6 \mathrm{~h}$ and $9 \mathrm{~h}$ after GalN/LPS

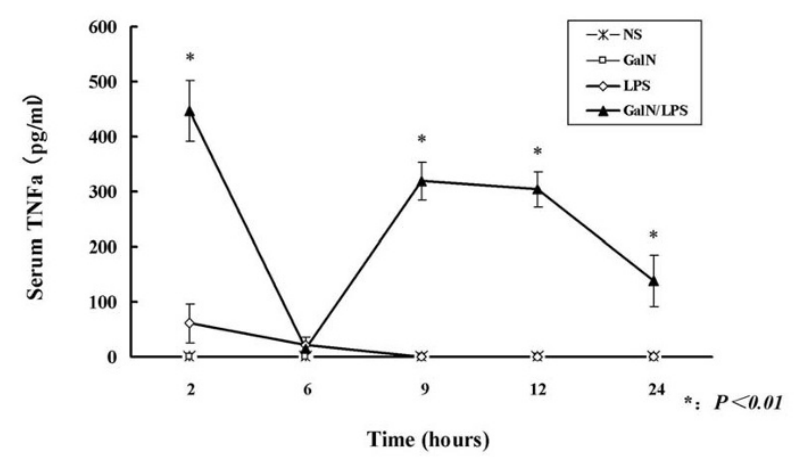

Figure I

Serum TNF- $\alpha$ levels. Serum TNF- $\alpha$ levels increased significantly in GalN/LPS-treated mice. Serum TNF- $\alpha$ levels were determined by ELISA and the data are expressed as the group mean \pm SE (eight mice per group). 
Table I: Serum ALT levels in ALF mice

\begin{tabular}{|c|c|c|c|c|c|c|}
\hline & & $2 \mathrm{~h}$ & $6 \mathrm{~h}$ & $9 \mathrm{~h}$ & $12 \mathrm{~h}$ & $24 \mathrm{~h}$ \\
\hline Groups & Number of mice & $\begin{array}{c}\text { ALT } \\
(\mathrm{U} / \mathrm{L})\end{array}$ & $\begin{array}{c}\text { ALT } \\
(\mathrm{U} / \mathrm{L})\end{array}$ & $\begin{array}{c}\text { ALT } \\
(\mathrm{U} / \mathrm{L})\end{array}$ & $\begin{array}{c}\text { ALT } \\
\text { (U/L) }\end{array}$ & $\begin{array}{c}\text { ALT } \\
(\mathrm{U} / \mathrm{L})\end{array}$ \\
\hline NS & 8 & $30.0 \pm 0.3$ & $29.3 \pm 1.0$ & $36.8 \pm 2.3$ & $32.5 \pm 0.7$ & $30.7 \pm 0.4$ \\
\hline LPS & 8 & $29.4 \pm 0.8$ & $27.1 \pm 2.0$ & $40.7 \pm 7.0$ & $34.5 \pm 3.4$ & $29.1 \pm 1.7$ \\
\hline GalN & 8 & $44.2 \pm 0.4$ & $63.4 \pm 1.0$ & $110.1 \pm 2.5$ & $97.4 \pm 1.2$ & $164.1 \pm 10.6$ \\
\hline GalN/LPS & 8 & $22.2 \pm 2.8$ & $2513.2 \pm 874.2^{\mathrm{a}}$ & $6235.5 \pm 912.4^{a}$ & $10215.8 \pm 967.7^{a}$ & $10250.6 \pm 1045.8^{a}$ \\
\hline TNF-alpha & 8 & $34.3 \pm 3.4$ & $32.7 \pm 4.6$ & $33.4 \pm 2.1$ & $34.6 \pm 3.9$ & $30.9 \pm 8.8$ \\
\hline GalN/TNFalpha & 8 & $33.7 \pm 2.9$ & $204.1 \pm 82.1^{a}$ & $4774.8 \pm 1118.0^{a}$ & $6177.8 \pm 1280.9 a$ & $4204.6 \pm 1118.6^{a}$ \\
\hline anti-TNF-alpha-lgG+GalN/LPS & 8 & -- & -- & $257.1 \pm 83.2^{b}$ & -- & -- \\
\hline anti-TNF-alpha R-IgG+GalN/LPS & 8 & -- & -- & $907.3 \pm 551.6^{b}$ & -- & -- \\
\hline
\end{tabular}

All values are expressed as mean \pm SE. a: $P<0.01$ vs Saline group, b: $P<0.01$ vs GalN/LPS co-injection group

administration. No bacterial invasion was observed in the control groups. The bacteria invaded at sites at which TJs were disrupted. It was evident that bacterial invasion of the intestinal mucosa of the GalN/LPS group occurred via pinocytosis, but this phenomenon was not observed in the other groups (Figure 3).

\section{Expression of ZO-I protein}

Immunohistochemical analysis revealed strong ZO-1 expression in the control groups. $\mathrm{ZO}-1$ was moderately expressed in intestinal tissue $2 \mathrm{~h}$ after GalN/LPS or GalN/ TNF- $\alpha$ treatment, and only traces remained $6 \mathrm{~h}$ after the treatments. By $9 \mathrm{~h}$ after the injections, it was difficult to detect positive signals for ZO-1, even in whole intestinal sections (Figure 4). ZO-1 expression was significantly increased in the two antibody-treated groups. Western blot analysis showed that ZO-1 expression decreased significantly in ALF mice, particularly $6 \mathrm{~h}$ and $9 \mathrm{~h}$ after the GalN/LPS or GalN/TNF- $\alpha$ injections (Figure 5). ZO-1 expression in the two antibody-treated groups was close to the normal range. These findings are consistent with the immunohistochemical results.

\section{Expression of ZO-I mRNA}

The ZO-1 and GAPDH RNAs used in the standard preparation were 327 bp and 335 bp long, respectively. We obtained a reasonable amplification curve, a standard curve, and a molten curve. The correlation coefficients of both standard curves were 0.999. Real-time PCR quantitative analyses showed that there were marked decreases in ZO-1 expression in ALF mice $6 \mathrm{~h}$ and $9 \mathrm{~h}$ after GalN/LPS or GalN/TNF- $\alpha$ treatment $(P<0.05)$ (Figure 6).

\section{Discussion}

The intestinal mucosal barrier is composed of mucosal fluid, microvilli, epithelial mucosal cell TJs and other special structures. TJs are the most important structures in the mucosal barrier. The mechanisms responsible for SBP include cytotoxic effects and alterations in the structure of the intestinal mucosa. Altered TJ structure in active liver cirrhosis has been described [18] preciously. However, it is rarely reported the ultrastructural characteristics and TJ structrue of the intestinal mucosa in ALF and the mechanisms that link ALF with SBP are still keep unclear.

In the present study, we found that severe damage to the intestinal mucosa occurred $9 \mathrm{~h}$ after GalN/LPS or GalN/ TNF- $\alpha$ treatment. Morphologic alterations to the intestinal mucosa included shedding of epithelial cells, fracturing of villi, fusion of adjacent villi, mucosal atrophy and edema. Disruption of TJs on enterocytes and damage to the mitochondria and endoplasm were also observed. The recent discovery that several polarity complexes are conserved in mammalian cells and are closely associated with TJs indicates that TJs play a vital role in establishing epithelial cell polarity [19]. Although damage to the intestinal mucosa plays a significant role in bacterial invasion of the body, the responsible mechanism remains to be elucidated.

Moreover, we observed that bacteria in the intestinal tract of ALF mice invaded the intestinal mucosa by pinocytosis at $9 \mathrm{~h}$ after GalN/LPS administration. It should be noted that we observed simultaneous disruptions in the integrity of the TJs. Some studies showed that the integrity of TJs is important for maintaining cellular polarity [20], a change in cell polarity may have facilitated bacterial invasion, and bacterial invasion may have occurred via the sites of disrupted TJs between intestinal mucosa epithelial cells.

ZO-1 is important for maintaining the integrity of intestinal mucosal TJs during pathological insults [21]. In our study, we found that the immunoreactive ZO-1 signal in the intestinal mucosa was significantly decreased in ALF mice, which was confirmed by the results of Western blot analysis. We also found that ZO-1 expression was significantly decreased in the intestinal tissue of human ALF patients compared with controls, which is consistent with 

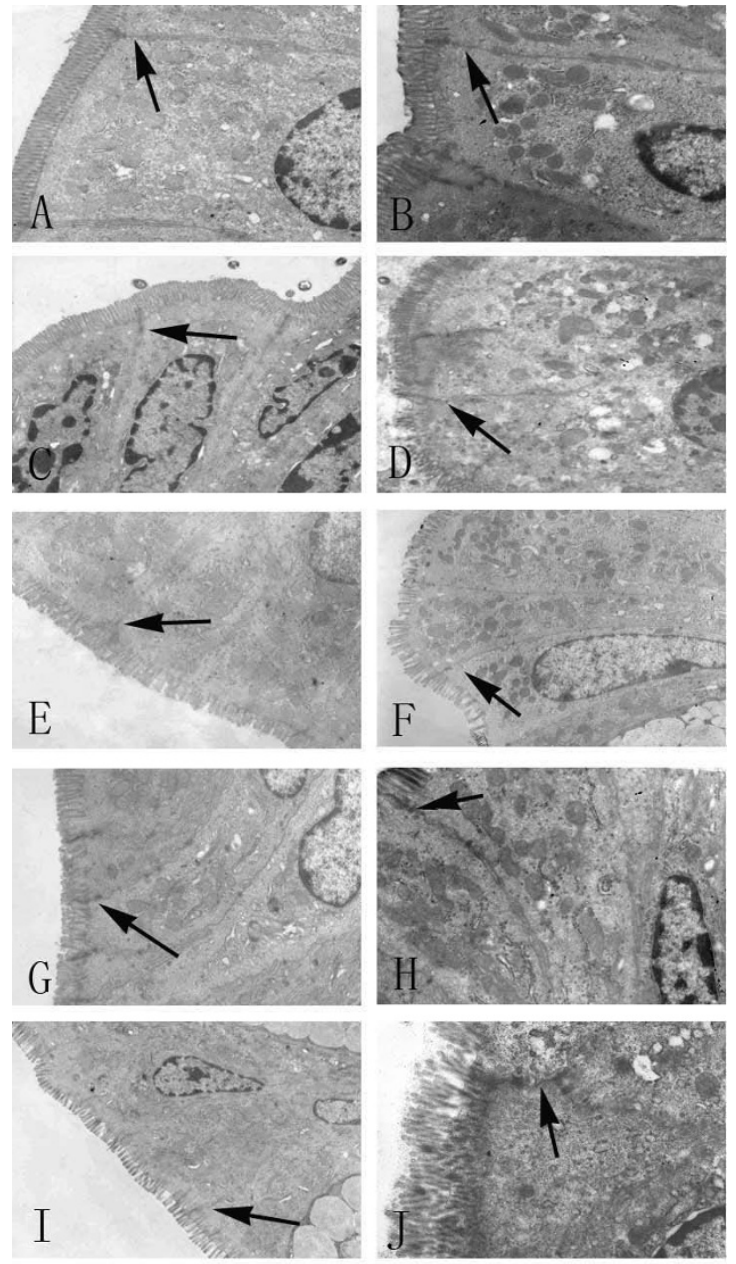

\section{Figure 2}

Transmission electron microscopy of mouse intestine. Transmission electron microscopy of mice intestine from the control groups (A, E, and F), the GalN/LPS group $(B, C$, and $D$ ), and groups that received antibodies prior to ALF induction ( $G$ and $H)$. A) Saline control group $(\times 30,000)$. Epithelial cells and TJ $(\rightarrow)$ were intact. B) At $2 \mathrm{~h}$ after injection $(\times \mid 20,000)$. Epithelial cells were swollen and shrunken. Microvilli and organelles were normal. TJs $(\rightarrow)$ were intact. C) At $6 \mathrm{~h}$ after injection $(\times 100,000)$. Microvilli were almost normal TJs $(\rightarrow)$ visible in this section were not disrupted. D) At $9 \mathrm{~h}$ after injection $(\times 60,000)$. The mitochondria of the endothelial cells were loose. TJs $(\rightarrow)$ were disrupted. Organelles were swollen and had reduced electron density. At $9 \mathrm{~h}$ after injection $(\times 10,000)$, some microvilli were loose. A TJ $(\rightarrow)$ was disrupted. E) LPS control group $(\times \mid 20,000)$. F) GalN control group $(\times 20,000)$. Epithelial cells were slightly shrunken and TJs $(\rightarrow)$ were intact. G) Anti-TNF- $\alpha$ IgG group $(\times 80,000)$. Epithelial cells were slightly shrunken and TJs $(\rightarrow)$ between endothelial cells were intact. H) Anti-TNF- $\alpha$ R I antibody group $(\times 80,000)$. The TJs $(\rightarrow)$ between the endothelial cells were intact. I) TNF- $\alpha$-treated group $(\times 50,000)$. TJ $(\rightarrow)$ were intact. J) At $9 \mathrm{~h}$ after GalN/TNF- $\alpha$ administration $(\times \mid 00,000)$. TJs $(\rightarrow)$ were disrupted.
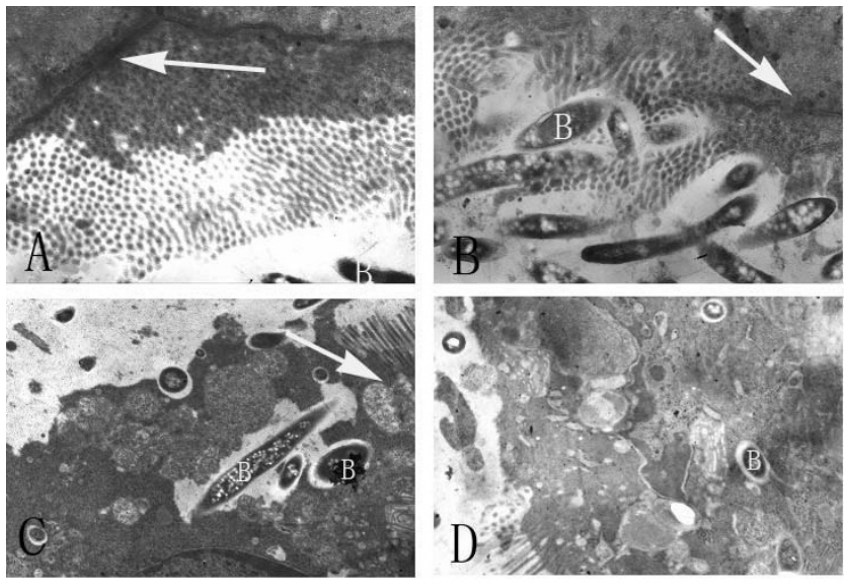

\section{Figure 3}

Morphology and bacterial invasion of colon samples in the GaIN/LPS-treated group. TJs through which bacterial invasion occurred (white color, $B$ ) were observed A: 2 h $(\times 100,000), B: 6 \mathrm{~h}(\times \mid 20,000), \mathrm{C}: 9 \mathrm{~h}(\times 60,000)$, and D: 12 $\mathrm{h}(\times 80,000)$ after GalN/LPS administration respectively. The microvilli $(M)$ were disrupted and the TJs through which bacterial invasion occurred were disrupted at $6 h(B), 9 h(C)$, and $12 \mathrm{~h}$ (D) after GalN/LPS administration. The TJs were disrupted or absent at $9 \mathrm{~h}(\mathrm{C})$ and $12 \mathrm{~h}(\mathrm{D})$ after GaIN/LPS administration.

our findings with animal models. Thus, we conclude that decreased ZO-1 expression causes TJ disruption.

To detect the key role in the mechanism of the TJ disruption and ZO-1 protein dicreased in ALF, in liver injury, inflammation involves sequential activation of signaling pathways that result in the production of pro-and antiinflammatory mediators. Among the pro-inflammatory mediators, the TNF- $\alpha$ and TNF- $\alpha$ R1 systems play central roles in the physiological regulation of intestinal barrier function $[22,23]$. TNF- $\alpha$ and IFN- $\gamma$ can induce intestinal epithelial barrier dysfunction [24]. In the present study, we found that in GalN/LPS-treated mice, TNF-a level reached a first peak at $2 \mathrm{~h}$ after GalN/LPS injection. We did not observe bacterial invasion of the intestinal mucosa or hepatocyte necrosis at this timepoint. The second peak occurred $9 \mathrm{~h}$ after the injection, at this timepoint we did observe bacterial invasion of the intestinal mucosa and hepatocyte necrosis. But bacterial invasion and hepatocyte necrosis were not observed in mice injected with either GalN or TNF- $\alpha$ alone. We thought that the first peak in TNF- $\alpha$ was the result of GalN/LPS injection, not ALF [23]. Then TNF- $\alpha$ was removed through degradation, whereas the second peak was released by activated macrophages, dendritic cells and kupffer cells, which was reported by Nakama T et al[24]. Moreover, some researchers have found that endotoxin (lipopolysaccharide: LPS) infection due to bacterial translocation is intimately 

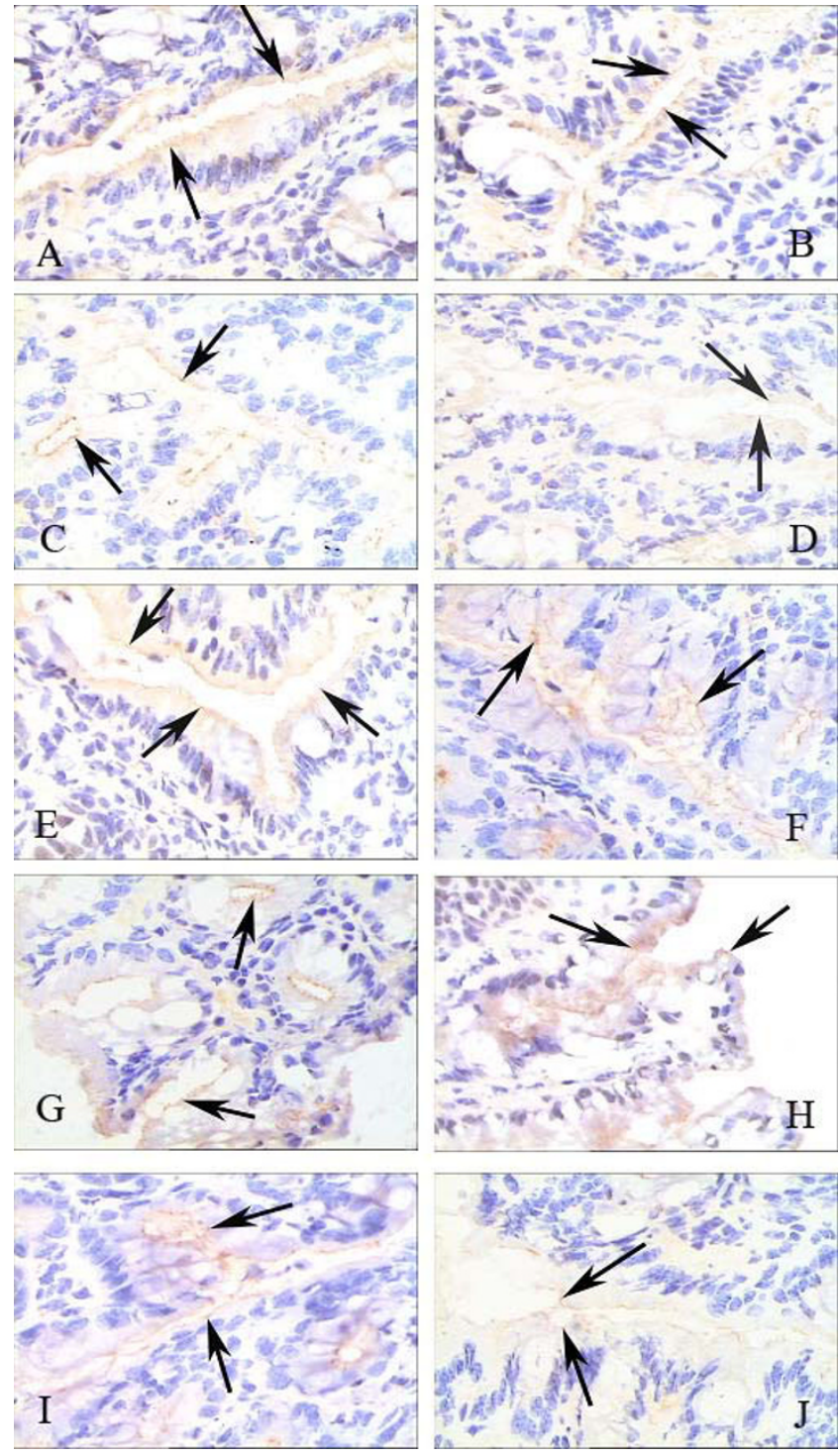

\section{Figure 4}

TJ protein expression in epithelial cells during ALF (original magnification, $\times 400$ ). A: NS-treated group, B: 2 $\mathrm{h}$ after GalN/LPS administration, C: $6 \mathrm{~h}$ after GaIN/LPS administration, D: $9 \mathrm{~h}$ after GalN/LPS administration, E: LPStreated group, F: GalN-treated group, G: anti-TNF- $\alpha$-treated group, $\mathrm{H}$ : anti-TNF- $\alpha$ R I-treated group, I: TNF- $\alpha$-treated group, J: $9 \mathrm{~h}$ after GalN/TNF- $\alpha$ administration. The mucosal tissue sections were double labeled for ZO-I (brown color). Labeled sections were analyzed immunohistochemically. Decreased ZO-I staining in the epithelial cells was observed at $9 \mathrm{~h}(\mathrm{D})$ after GalN/LPS and GalN/TNF- $\alpha(\mathrm{J})$ administration. In contrast to ZO-I expression in colon tissue $2 \mathrm{~h}$ (B) and $6 \mathrm{~h}(\mathrm{C})$ after GalN/LPS administration, ZO-I expression in the NS group (A), LPS group (E), D-GalN group (F), antiTNF- $\alpha \lg G$ group $(G)$, anti-TNF- $\alpha$ receptor I group $(H)$, and TNF- $\alpha$ group (I) were not down-regulated (arrows indicate ZO-I). involved in the organ failure. LPS that has translocated into portal blood binds to LPS-binding protein (LBP), was transported to the monocytes and Kupffer cells in liver sinusoids. Inflammatory cytokines such as TNF- $\alpha$ et al are produced and released by monocytes and Kupffer cells [25]. This study show that the bacterial invasion may play a role in the occurring of the second TNF- $\alpha$ peak, their relationship needs to be further investigated.

In addition, we found that the decrease in ZO-1 expression was correlated with an increase in the serum level of TNF- $\alpha$. Many researchers have found that some cytokines can induce endocytosis of TJ proteins [26] and internalization of epithelial TJ proteins [27]. Reductions in levels of the tight junction protein, occludin, in intestinal epithelial cells may be caused by the production of TNF- $\alpha$ in mice with fulminant hepatic failure [28]. TNF- $\alpha$-induced increase in Caco- 2 cell TJ permeability was mediated by NF-kappa B activation. The increase in permeability was associated with NF-kappa B-dependent downregulation of $\mathrm{ZO}-1$ protein expression and altered junctional localization [29-31]. In this study we found that event chronology is more important because it gives us some vital clues. The first TNF- $\alpha$ peak $2 \mathrm{~h}$ post GalN/LPS injection may induce the $\mathrm{ZO}-1$ down expression and the tight junction disruption observed at $9 \mathrm{~h}$. The pathophysiological processes of ALF in vivo is complicated, TNF- $\alpha$ plays an important role. TNF- $\alpha$ perhaps is an initiator which can induce more cytokines such as IL- 6 and IFN- $\gamma$, which can aggravate liver injury and initiate the development of ALF, and the disruption of TJ intestinal. The first TNF- $\alpha$ peak occurred at $2 \mathrm{~h}$ post injection may induce the $\mathrm{ZO}-1$ down expression and the tight junction disruption observed at 9 $\mathrm{h}$ timepoint.

There was no any damage on TJs and no decrease in the expression of ZO-1 on the mice group accepted recombinant TNF- $\alpha$, the purpose of this study was to discolse the change of TJ in ALF process, a positive finding could be observed if mice accepted a high dose of recombinant TNF- $\alpha$, a further study need to performed in the future.

In order to study the role of TNF- $\alpha$ further, we used TNF$\alpha$ antibody and anti-TNFR antibody. TNF- $\alpha$ antibody could neutralize the quantity of TNF- $\alpha$, and anti-TNFR antibody could block the combination between TNF- $\alpha$ and TNF- $\alpha$ R. When TNF- $\alpha$ was blockaded with anti-TNF$\alpha$ IgG antibody or anti-TNF- $\alpha$ R1 antibody, there was a significant decrease in the mice of liver failure and no bacterial invasion or hepatocyte necrosis. These data indicate that TNF- $\alpha$ is an important mediator of bacterial invasion of the intestinal mucosa during ALF. Moreover, we found that a significant reduction in ZO-1 mRNA expression in ALF mice and a significant induction of ZO-1 mRNA expression in ALF mice pretreated with either anti-TNF- $\alpha$ 


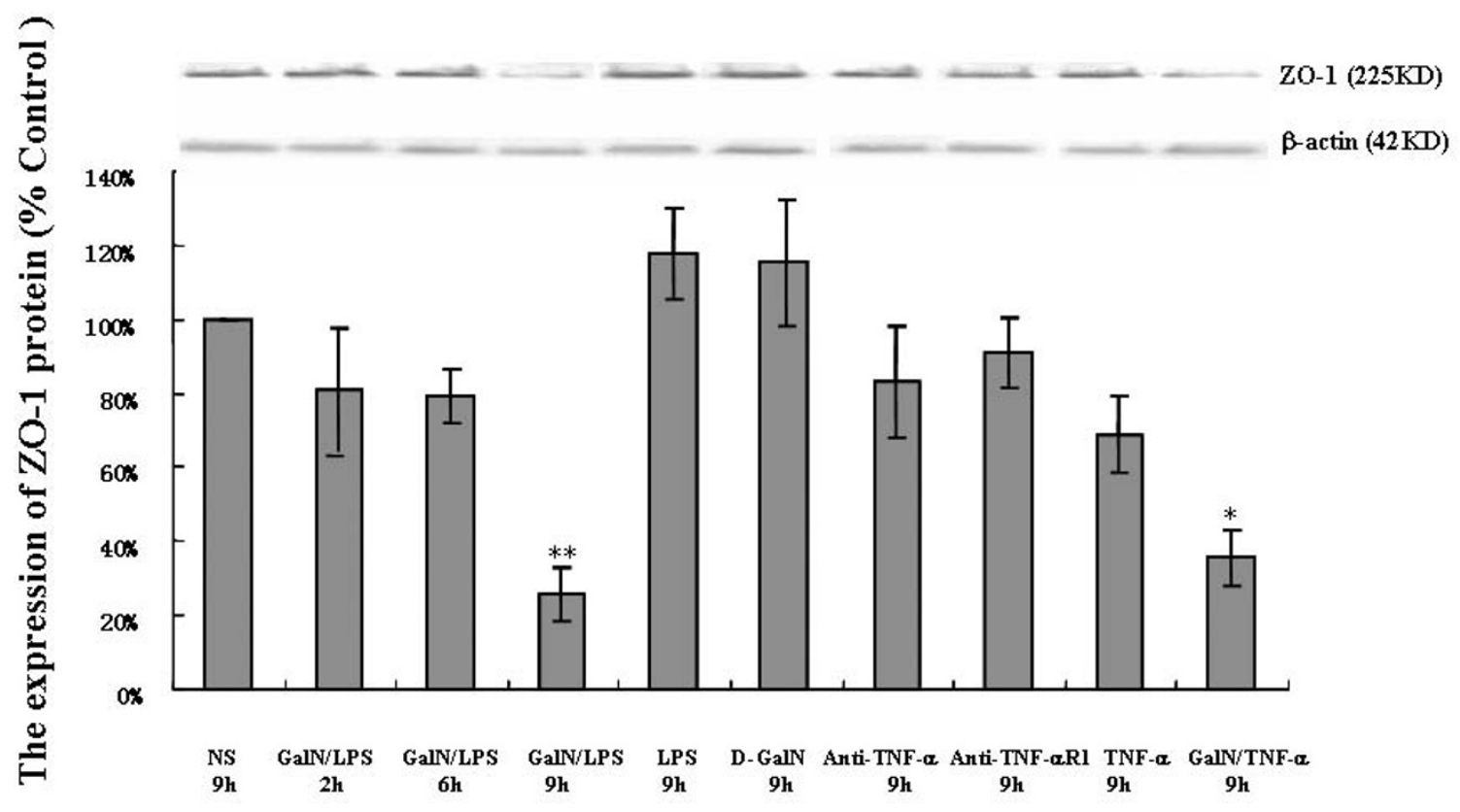

The expression of ZO-1 protein in ALF and control groups $\left({ }^{\star \star} P<0.01,{ }^{\star} P<0.05\right)$

\section{Figure 5}

Mucosal colonic tissues from control and ALF mice were analyzed for ZO-I expression. Western blot analyses indicated that ZO-I expression was altered in mice with ALF. ZO-I expression was significantly decreased at $9 \mathrm{~h}$ in GaIN/LPStreated mice $(20.1 \mathrm{I} \pm 7.37 \%)$ and GalN/TNF- $\alpha$-treated mice $(35.47 \pm 7.34 \%)$ compared with the NS control $(100.00 \pm 0.00 \%)$ and the other groups. No differences were observed in actin expression in the ALF model compared to the control. ZO-I expression was unchanged at $2 \mathrm{~h}$ in the ALF group compared with the NS control. Each bar represents the mean \pm SE $(n=3$ mice per group). Insets: representative Western blots. Lane I, NS; lane 2, $2 \mathrm{~h}$ after GaIN/LPS administration; lane 3, $6 \mathrm{~h}$ after GaIN/LPS administration; lane 4, $9 \mathrm{~h}$ after GaIN/LPS administration; lane 5, LPS; lane 6, D-GalN; lane 7, anti-TNF- $\alpha$-treated group; lane 8, anti-TNF- $\alpha$ RI-treated group; lane 9, TNF- $\alpha$-treated group; lane 10, $9 \mathrm{~h}$ after GalN/TNF- $\alpha$ administration. Statistical significance was determined using a one-way ANOVA followed by the Tukey test. $* P<0.05, * * P<0.01$ vs. the NS control group.

IgG antibody or anti-TNF- $\alpha$ receptor1 antibody. These findings suggest that TNF- $\alpha$ downregulates $\mathrm{ZO}-1$ protein expression in intestinal tissue by inhibiting ZO-1 mRNA expression.

\section{Conclusion}

This study demonstrated the changes in intestinal mucosal morphology in mice with ALF. These changes were associated with disruption of TJ structure, changes in epithelial cell microvilli (disarrangement, distortion, and swelling or shrinkage) and mitochondrial matrices (mitochondrial swelling and disturbance of cristae). The disruption of the intestinal mucosa and consequent bacterial invasion of the body in ALF may be caused by reduced levels of the TJ-associated protein, $\mathrm{ZO}-1$, the production of which was not controlled by transcription. These changes were caused by an elevated serum level of TNF- $\alpha$, as they were absent when TNF- $\alpha$ was blocked by anti-TNF- $\alpha$ IgG antibody or anti-TNF- $\alpha$ R1 antibody. This study confirmed that TNF- $\alpha$ damages TJs and affects the expression of ZO-1 protein in vivo. TNF- $\alpha$ also may participate in the pathophysiological mechanism of SBP complicated to ALF. The mechanism of TNF- $\alpha$-induced changes during ALF is complex and arrants further study.

\section{List of abbreviations}

ALF: Acute liver failure; GalN: D-galactosamine; LPS: lipopolysaccharide; TJ: tight junction; ZO-1: zona occludens 1; TEM: transmission electron microscopy; TNF- $\alpha$ : tumor necrosis factor-a; WB: Western blot; ALT: alanine transaminase; SBP: spontaneous bacterial peritonitis; TEM: transmission electron microscopy; TNF- $\alpha$ R: tumor necrosis factor-a receptor; NS: normal saline.

\section{Competing interests}

The authors declare that they have no competing interests.

\section{Authors' contributions}

HLS and PL participated in the conception and design of the study and drafted the manuscript. HLS and SL exe- 


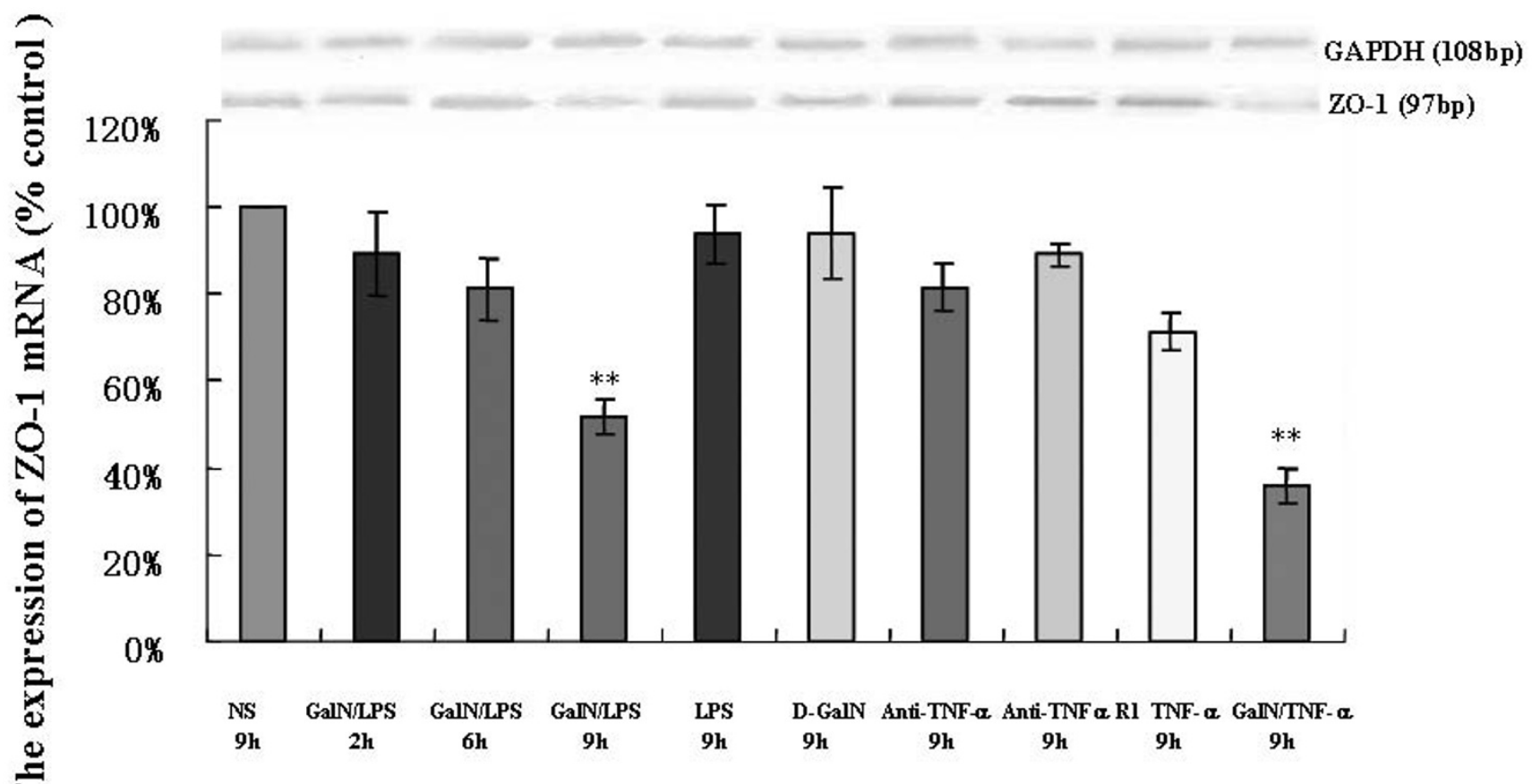

\section{Real-time q PCR on ZO-1 in ALF and control groups $\left({ }^{\star \star} P<0.01\right)$}

\section{Figure 6}

Real-time quantitative RT-PCR for ZO-I mRNA in the ALF groups and other control groups. ZO-I mRNA level was decreased at $9 \mathrm{~h}$ in mice with ALF. Total RNA derived from each tissue was reverse transcribed and subjected to real time quantitative RT-PCR to evaluate ZO-I and glyceraldehyde-3-phosphate dehydrogenase (GAPDH) mRNA levels. Results are expressed as the number of ZO-I amplicons per 104 GAPDH amplicons. Bars represent the mean value for each group. The only significant difference in ZO-I mRNA level between the ALF and control groups (NS: $100.00 \pm 0.00 \%$ ) was at $9 \mathrm{~h}$. At this time, there was decrease in the level of full-length ZO-I mRNA in the ALF mice. At all other times, there was no difference between the ALF group and the other groups, which is consistent with our immunohistochemistry results.

cuted the study. HLS analyzed the data. All authors have read and approved the final manuscript.

\section{Acknowledgements}

We thank Zhang Fuhui and Su Ruoping of the electron microscopy unit of China Medical University for their technical help and Zong Zhihong of the Biochemistry Department of China Medical University for Technical Assistance. This study was supported by the National Science Foundation of China (grant no. 30670947) and National Ministry of Health, China (grant no. 97100252).

\section{References}

I. Rimola A, García-Tsao G, Navasa M, Piddock LJ, Planas R, Bernard B, Inadomi JM: Diagnosis, treatment and prophylaxis of spontaneous bacterial peritonitis: a consensus document. International Ascites Club. J Hepatol 2000, 32: I42-153.

2. Thanopoulou AC, Koskinas JS, Hadziyannis SJ: Spontaneous bacterial peritonitis (SBP): clinical, laboratory, and prognostic features. A single-center experience. Eur J Intern Med 2002, 13:194-198.

3. Franca AV, De Souza JB, Silva CM, Soares EC: Long-term prognosis of cirrhosis after spontaneous bacterial peritonitis treated with ceftriaxone. J Clin Gastroenterol 200I, 33:295-298.

4. Such J, Frances R, Munoz C, Zapater P, Casellas JA, Cifuentes A, Rodriguez-Valera F, Pascual S, Sola-Vera J, Carnicer F, Uceda F, Palazon
JM, Perez-Mateo M: Detection and identification of bacterial DNA in patients with cirrhosis and culture-negative, nonneutrocytic ascites. Hepatology 2002, 36: |35-|4|.

5. Muto Y, Nouri-Aria KT, Meager A, Alexander GJ, Eddleston AL, Williams R: Enhanced tumour necrosis factor and interleukin- $I$ in fulminant hepatic failure. Lancet 1988, 2:72-74.

6. Wang JH, Redmond HP, Watson RW, Bouchier-Hayes D: Role of lipopolysaccharide and tumor necrosis factor-alpha in induction of hepatocyte necrosis. Am J Physiol 1995, 269:G297-304.

7. Leist M, Gantner F, Bohlinger I, Tiegs G, Germann PG, Wendel A: Tumor necrosis factor-induced hepatocyte apoptosis precedes liver failure in experimental murine shock models. Am J Pathol 1995, 146:1220-1234.

8. Lv S, Song HL, Wang JY, Liu P: Blood brain barrier permeability in acute liver necrosis of mice. World Chin J Digesto 2004, I 2: | 346- I 348 [http://www.wignet.com// 009-3079//2//346.pdf].

9. Corredor J, Yan F, Shen CC, Tong W, John SK, Wilson G, Whitehead $\mathrm{R}$, Polk DB: Tumor necrosis factor regulates intestinal epithelial cell migration by receptor-dependent mechanisms. Am J Physiol Cell Physiol 2003, 284:C953-96I.

10. Poddar U, Thapa BR, Prasad A, Sharma AK, Singh K: Natural history and risk factors in fulminant hepatic failure. Arch Dis Child 2002, 87:54-56.

II. Morita K, Itoh M, Saitou M, Ando-Akatsuka Y, Furuse M, Yoneda K, Imamura S, Fujimoto K, Tsukita S: Subcellular distribution of tight junction-associated proteins (occludin, ZO-I, ZO-2) in rodent skin. J Invest Dermatol 1998, I 1 0:862-866.

12. Haskins J, Gu L, Wittchen ES, Hibbard J, Stevenson BR: ZO-3, a novel member of the MAGUK protein family found at the 
tight junction, interacts with ZO-I and occludin. I Cell Biol 1998, 141:199-208.

13. Furuse M, Fujita K, Hiiragi T, Fujimoto K, Tsukita S: Claudin-I and 2: novel integral membrane proteins localizing at tight junctions with no sequence similarity to occludin. J Cell Biol 1998, I 41: 1539-1550.

14. Furuse M, Hirase T, Itoh M, Nagafuchi A, Yonemura S, Tsukita S, Tsukita S: Occludin a novel integral membrane protein localizing at tight junctions. J Cell Biol 1993, I 23:1777-1788.

15. Itoh M, Nagafuchi A, Moroi S, Tsukita S: Involvement of ZO-I in cadherin-based cell adhesion through its direct binding to alpha catenin and actin filaments. / Cell Biol I997, I38:18I-I 92.

16. Mitic LL, Van Itallie CM, Anderson JM: Molecular physiology and pathophysiology of tight junctions I. Tight junction structure and function: lessons from mutant animals and proteins. Am J Physiol Gastrointest Liver Physiol 2000, 279:G250-254.

17. Gonzalez-Mariscal L, Betanzos A, Avila-Flores A: MAGUK proteins structure and role in the tight junction. Semin Cell Dev Biol 2000, II:315-324.

18. Such J, Guardiola JV, de Juan J, Casellas JA, Pascual S, Aparicio JR, SolaVera J, Perez-Mateo M: Ultrastructural characteristics of distal duodenum mucosa in patients with cirrhosis. Eur J Gastroenterol Hepatol 2002, 14:37|-376.

19. Roh MH, Margolis B: Composition and function of PDZ protein complexes during cell polarization. Am J Physiol Renal Physiol 2003, 285:F377-387.

20. Matter K, Balda MS: Signalling to and from tight junctions. Nat Rev Mol Cell Biol 2003, 4:225-236.

21. Ma TY, Iwamoto GK, Hoa NT, Akotia V, Pedram A, Boivin MA, Said HM: TNF-alpha-induced increase in intestinal epithelial tight junction permeability requires NF-kappa B activation. Am J Physiol Gastrointest Liver Physiol 2004, 286:G367-G376.

22. Wang F, Graham EV, Wang Y, Witkowski ED, Schwarz BT, Turner JR: Interferon-gamma and tumor necrosis factor-alpha synergize to induce intestinal epithelial barrier dysfunction by upregulating myosin light chain kinase expression. Am J Pathol 2005, 166:409-419.

23. Tiegs $G$, Wolter $M$, Wendel $A$ : Tumor necrosis factor is a terminal mediator in galactosamine/endotoxin-induced hepatitis in mice. Biochem Pharmacol 1989, 15;38:627-63I.

24. Nakama T, Hirono S, Moriuchi A, Hasuike S, Nagata K, Hori T, Ido A, Hayashi $\mathrm{K}$, Tsubouchi $\mathrm{H}$ : Etoposide prevents apoptosis in mouse liver with D-galactosamine/lipopolysaccharideinduced fulminant hepatic failure resulting in reduction of lethality. Hepatolog 200I, 33: |44I-1450.

25. Usui $M$, Kawarada $Y$ : Endotoxin and its binding protein in organ failure. Nippon Geka Gakkai Zasshi 1998, 99:504-509.

26. Utech M, Ivanov Al, Samarin SN, Bruewer M, Turner JR, Mrsny RJ, Parkos CA, Nusrat A: Mechanism of IFN-gamma-induced endocytosis of tight junction proteins: myosin II-dependent vacuolarization of the apical plasma membrane. $\mathrm{Mol} \mathrm{Biol} \mathrm{Cel}$ 2005, 16:5040-5052.

27. Bruewer M, Utech M, Ivanov AI, Hopkins AM, Parkos CA, Nusrat A: Interferon-gamma induces internalization of epithelial tight junction proteins via a macropinocytosis-like process. FASEB J 2005, 19:923-33.

28. Cui W, Wang Y, Ma L, Wen Y, Liu P: The impact of tumor necrosis factor alpha on expression of intestinal epithelial tight junction protein occluding in fulminant hepatic failure mice model. Zhonghua Nei Ke Za Zhi 2007, 46:478-48I.

29. Song HL, Lu S, Ma L, Li Y, Liu P: Effect of TNF-alpha on tight junctions between the epithelial cells of intestinal mucosal barrier. World Chin J Digestol 2004, I2:1303-1306 [http:// www.wignet.com/1009-3079//2//303.pdf].

30. Schmitz H, Fromm M, Bentzel CJ, Scholz P, Detjen K, Mankertz J, Bode H, Epple HJ, Riecken EO, Schulzke JD: Tumor necrosis factor-alpha (TNF-alpha) regulates the epithelial barrier in the human intestinal cell line HT-29/B6. J Cell Sci 1999, I I 2:137-146.

31. Ma TY, Iwamoto GK, Hoa NT, Akotia V, Pedram A, Boivin MA, Said $H M$ : TNF-alpha-induced increase in intestinal epithelial tight junction permeability requires NF-kappa B activation. Am J Physiol Gastrointest Liver Physiol 2004, 286:G367-376.

\section{Pre-publication history}

The pre-publication history for this paper can be accessed here:

http://www.biomedcentral.com/1471-230X/9/70/pre pub
Publish with Bio Med Central and every scientist can read your work free of charge

"BioMed Central will be the most significant development for disseminating the results of biomedical research in our lifetime. "

Sir Paul Nurse, Cancer Research UK

Your research papers will be:

- available free of charge to the entire biomedical community

- peer reviewed and published immediately upon acceptance

- cited in PubMed and archived on PubMed Central

- yours - you keep the copyright

Submit your manuscript here:

http://www.biomedcentral.com/info/publishing_adv.asp
BiolMedcentral 